\title{
Cytomorphological Patterns of Lymphadenopathy: A 5 Years Retrospective Study in a Tertiary Care Centre
}

\author{
Dr. Sujata Ganguli ${ }^{1}$, Dr. Anjan Kumar Das ${ }^{2 *}$
}

\footnotetext{
${ }^{1}$ Senior Resident, Department of Pathology, Ghatal Superspeciality Hospital, Ghatal, West Bengal, Pin-721212, India

${ }^{2}$ Professor and Head, Department Of Pathology, Coochbehar Medical College, West Bengal, Pin-736101, India
}

DOI: $10.36347 /$ sjams.2020.v08i10.029

| Received: 07.10.2020 | Accepted: 21.10.2020 | Published: 26.10.2020

*Corresponding author: Dr. Anjan Kumar Das

Abstract

Original Research Article

Background: Lymphadenopathy is a common presenting feature in various non-neoplastic and neoplastic lesions. Fine needle aspiration cytology is a simple, quick, inexpensive and minimally invasive technique that can be used as a outpatient procedure to diagnose lymphadenopathies. This study was undertaken to assess the various causes of lymphadenopathy through FNAC, to see the distribution of lesions with respect to age, location and gender, and to assess the accuracy of lymph node FNAC in various non-neoplastic and neoplastic conditions. Methods: This was a retrospective study where total 2496 cases of lymph node FNAC were studied from august 2011 to July 2016 in the Department of Pathology of Calcutta National Medical College, Kolkata. The cytomorphologic features seen in the aspirates were analysed. Results: In this study, 2496 cases of lymphadenopathy were analysed. The age of the patients ranged from 3 months to 80 years. The male to female ratio was 1.12:1. Maximum number of cases were found to be in the age group of 11 to 20 years $(24.2 \%)$. The most common lesion encountered was granulomatous lymphadenitis followed by reactive hyperplasia. Histopathology examination was done in 79 cases, out which only 3 cases showed discordance. Conclusion: FNAC is a safe, rapid and cost effective method in establishing the diagnosis in majority of cases of lymphadenopathy. It is therefore an important diagnostic procedure and prevents the patient from undergoing unnecessary surgery.

Keywords: Lymphadenopathy, fine needle aspiration cytology.

Copyright $\left({ }_{0} 2020\right.$ The Author(s): This is an open-access article distributed under the terms of the Creative Commons Attribution 4.0 International License (CC BY-NC 4.0) which permits unrestricted use, distribution, and reproduction in any medium for non-commercial use provided the original author and source are credited.

\section{INTRODUCTION}

Lymphadenopathy is a commonly encountered clinical entity in pathology laboratories. Enlarged lymph nodes are usually easily accessible for fine needle aspiration and hence FNAC is a very simple and important diagnostic tool for lymph node lesions.

Cytological examination of FNA smears help to determine whether lymphadenopathy is due to reactive hyperplasia infection, metastasis or lymphoproliferative disorders.

FNAC followed by confirmation by histopathology (in appropriate cases) helps in reducing morbidity and mortality by starting specific therapy. The preliminary assessment is therefore based on routine cytologic smears.

\section{Aims AND OBJECTIVES}

- To study the incidence of lymphadenopathy presenting for FNAC in a tertiary care hospital
- To study the spectrum of cytopathological features in patients presenting with lymphadenopathy

- To assess the correlation between results of cytology and clinical follow up, and correlation between cytology and histopathology investigations in applicable cases

\section{Materials}

- Disposable syringe(10cc) with needle(22-27 gauge)

- Clean glass slides

- Leishman-Giemsa stain, Haematoxylin and Eosin stain, Ziehl- Neelsen stain, Papanicolaou stain

- Knife for grossing the specimens

- Formalin for fixation

- Alcohol and Xylene for processing

- Paraffin wax for block preparation

- Microtome for section cutting 


\section{MeTHODS}

- Type of study-retrospective cross sectional hospital based study

- $\quad$ Study period-August 2011 to July 2016

- Study area-Department of Pathology, Calcutta National Medical college and Hospital

- Study population-patients presenting with lymphadenopathy referred from various departments (OPD and IPD) for FNAC examination (2496 cases) and formalinised lymph node biopsy samples sent for histopathological examination(79 cases)

- INCLUSION CRITERIA: Patients of different age groups attending OPD and patients admitted in Calcutta National Medical College and Hospital presenting with lymphadenopathy and referred to the Department of Pathology for FNAC.

- EXCLUSION CRITERIA: Patients who declined to give consent for FNAC examination.

\section{Result Analysis}

The total number of FNAC $\mathrm{s}$ done in the Department of Pathology during the study period was 11128 of which 2496 cases were performed for lymphadenopathies. The incidence of FNAC $\mathrm{s}$ for lymphadenopathies among total FNACs done was calculated to be $22.4 \%$.

Of the 2496 cases of FNAC samples studied, $29(1.16 \%)$ had been done under radiological guidance.

Male patients slightly outnumbered female patients $(1.2: 1)$.

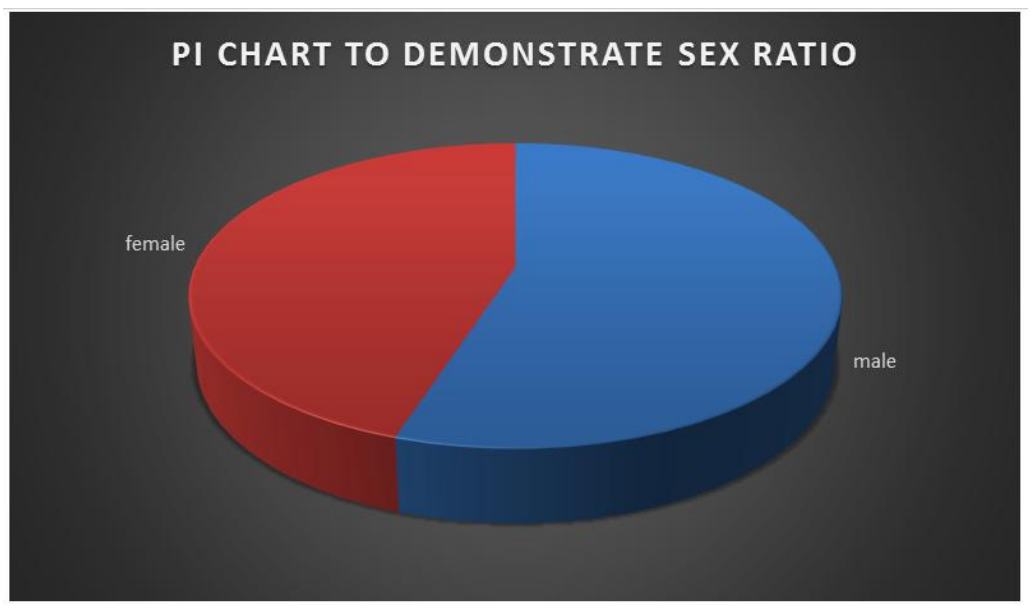

Distribution of Cases of Lymphadenopathies According To Anatomical Location

The commonest location was found to be cervical region (1672 cases, i.e. 67\%) followed by supraclavicular, inguinal, axillary and other groups which included: - submental (28 cases), mediastinal (19 cases), and epitrochlear (3 cases).

\section{SCHEMATIC ILLUSTRATION}

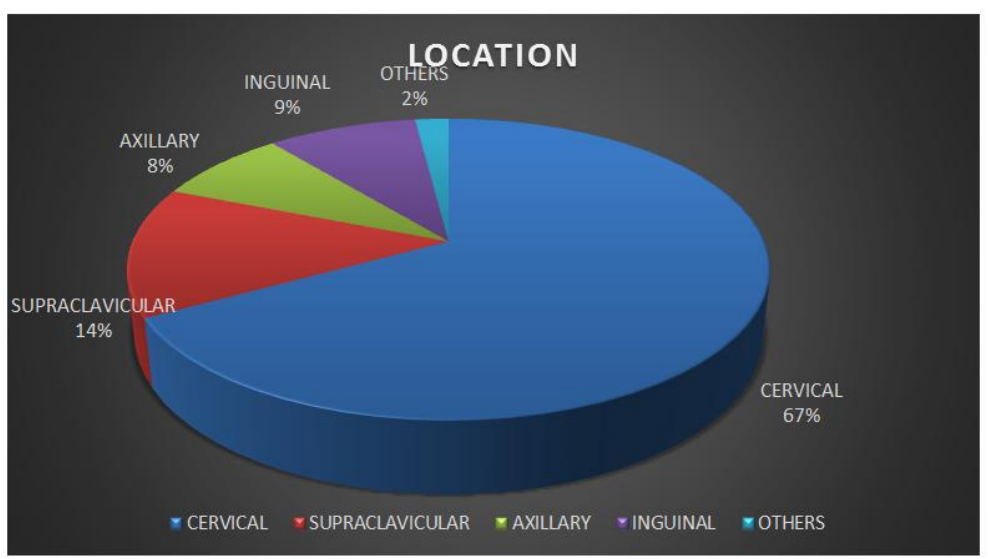

Distribution of Cases of Lymphadenopathies According To Age 


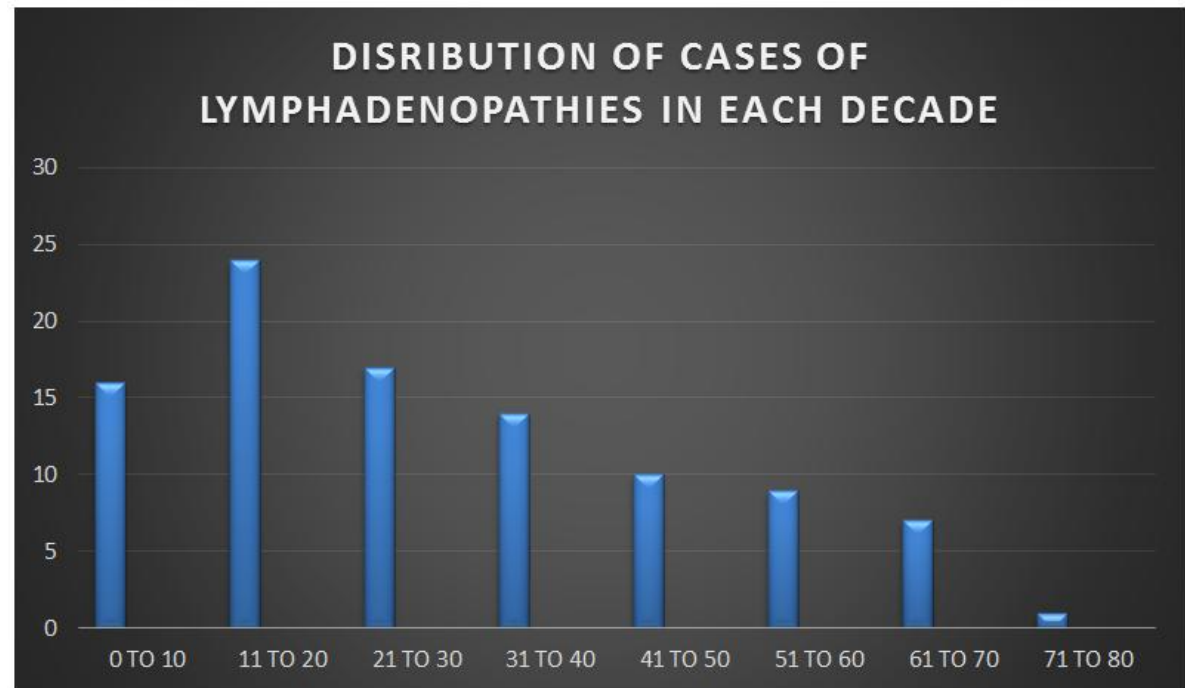

Disribution of Cases of Lymphadenopathies in Each Decade

Distribution of Cases of Lymphadenopathies According To Cytological Diagnosis

\begin{tabular}{|l|l|}
\hline CYTOPATHOLOGICAL DIAGNOSIS & \multicolumn{1}{c|}{ NUMBER OF CASES } \\
\hline $\begin{array}{l}\text { GRANULOMATOUS LESION A.CASEATING (tubercular } \\
\text { lymphadenitis) B.NONCASEATING }\end{array}$ & $\begin{array}{l}1132 \text { CASES }(45.4 \%), \text { AFB POSITIVE CASES } \\
\text { WERE 808(71.4\%) }\end{array}$ \\
\hline REACTIVE LYMPHADENITIS & 1065 CASES $(42.7 \%)$ \\
\hline METASTATIC LYMPH NODE & 152 CASES $(6.08 \%)$ \\
\hline LYMPHOPROLIFERATIVE LESION & $\begin{array}{l}127 \text { CASES }(5.1 \%) \\
73 \text { CASES HODGKINS AND 54 CASES NON } \\
\text { HODGKINS LYMPHOMA }\end{array}$ \\
\hline INCONCLUSIVE & 20 CASES $(0.95 \%)$ \\
\hline TOTAL & 2496 CASES \\
\hline
\end{tabular}

\begin{tabular}{|c|c|c|c|c|c|}
\hline \multicolumn{6}{|c|}{ Distribution of Cases of Lymphadenopathies According To Cytology Results in Each Age Decade } \\
\hline AGE & $\begin{array}{l}\text { GRANULOMATOUS } \\
\text { LYMPHADENITIS }\end{array}$ & $\begin{array}{l}\text { REACTIVE } \\
\text { LYMPHADENITIS }\end{array}$ & $\begin{array}{l}\text { HODGKINS } \\
\text { LYMPHOMA }\end{array}$ & $\begin{array}{l}\text { NON } \\
\text { HODGKINS } \\
\text { LYMPHOMA }\end{array}$ & METASTATIC \\
\hline 0-10 YEARS & 152 & 244 & 0 & 1 & 0 \\
\hline 11-20 YEARS & 266 & 318 & 15 & 2 & 0 \\
\hline 21-30 YEARS & 248 & 176 & 13 & 1 & 1 \\
\hline 31-40 YEARS & 174 & 139 & 19 & 3 & 5 \\
\hline 41-50 YEARS & 121 & 68 & 17 & 10 & 34 \\
\hline 51-60 YEARS & 96 & 62 & 7 & 19 & 48 \\
\hline 61-70 YEARS & 59 & 44 & 2 & 17 & 59 \\
\hline $71-80$ & 16 & 14 & 0 & 1 & 5 \\
\hline TOTAL & 1132 & 1065 & 73 & 54 & 152 \\
\hline
\end{tabular}

Distribution of Types of Metastasis Found In Lymph Node FNAC

\begin{tabular}{|l|l|}
\hline CYTOLOGICAL DIAGNOSIS & PERCENTAGE \\
\hline SQUAMOUS CELL CARCINOMA & $42 \%$ \\
\hline ADENOCARCINOMA & $30 \%$ \\
\hline PAPILLARY CARCINOMA OF THYROID & $9 \%$ \\
\hline MALIGNANT MELANOMA & $8 \%$ \\
\hline MIXED GERM CELL TUMOUR & $6 \%$ \\
\hline POORLY DIFFERENTIATED CARCINOMA & $5 \%$ \\
\hline
\end{tabular}


Table Showing Correlation between Cytological and Histopathological Diagnosis of Lymphadenopathies (79

Cases)

\begin{tabular}{|c|c|c|c|}
\hline $\begin{array}{l}\text { CYTOLOGICAL } \\
\text { DIAGNOSIS }\end{array}$ & HISTOLOGICAL DIAGNOSIS & $\begin{array}{l}\text { HISTOLOGICAL } \\
\text { CONCORDANCE }\end{array}$ & $\begin{array}{l}\text { HISTOLOGICAL } \\
\text { DISCORDANCE }\end{array}$ \\
\hline $\begin{array}{l}\text { REACTIVE } \\
\text { LYMPHADENITIS(6 } \\
\text { CASES) }\end{array}$ & $\begin{array}{l}5 \text { CASES: REACTIVE } \\
\text { LYMPHADENITIS } \\
1 \text { CASE:HODGKIN LYMPHOMA }\end{array}$ & 5 CASES & 1 CASE \\
\hline $\begin{array}{l}\text { GRANULOMATOUS } \\
\text { LYMPHADENITIS( } 3 \\
\text { CASES })\end{array}$ & $\begin{array}{l}2 \text { CASES:GRANULOMATOUS } \\
\text { LYMPHADENITIS } \\
\text { 1 CASE:REACTIVE } \\
\text { LYMPHADENITIS }\end{array}$ & 2 CASES & 1 CASE \\
\hline $\begin{array}{l}\text { METASTATIC } \\
\text { DEPOSIT(51 CASES) }\end{array}$ & 51 CASES:METASTASIC DEPOSIT & 51 CASES & NONE \\
\hline $\begin{array}{l}\text { LYMPHOPROLIFERATIVE } \\
\text { DISORDER(19 CASES) }\end{array}$ & $\begin{array}{l}18 \\
\text { CASES:LYMPHOPROLIFERATIVE } \\
\text { DISORDER } \\
\text { 1 CASE:REACTIVE } \\
\text { LYMPHADENITIS }\end{array}$ & 18 CASES & 1 CASE \\
\hline TOTAL(79 CASES) & & 76 CASES & 3 CASES \\
\hline
\end{tabular}

\section{DISCUSSION}

The incidence of FNAC $\mathrm{s}$ done for lymphadenopathies among total number of FNAC $\mathrm{s}$ performed was $22.4 \%$.

A male preponderance was noted in this study. Similar male preponderance was noted by Patel M. M et al., Kumar $\mathrm{N}$ et al., and Hemalatha A et al., [1-3].

In this study, out of 2496 attempted cases, satisfactory evaluation could be done in 2476 cases, barring 20 cases which were inconclusive.

In this study the commonest cytological diagnosis of lymphadenopathy was granulomatous (caseating and noncaseating) lymphadenitis (1132 cases), with a peak at the age group of 11-20 years (266 cases). Similar findings were also observed by Shilpa $\mathrm{G}$ et al., and Kumar $\mathrm{N}$ et al., [2, 4].

The commonest anatomical site of lymphadenopathy was cervical (67\% cases). Similar findings were also observed by Shilpa $\mathrm{G}$ et al., Wilkinson et al., and Shrivastav et al., [4-6].

In this study, out of 1132 cases of granulomatous lymphadenitis, 808 cases $(71.4 \%)$ were positive for AFB which is similar to the study conducted by Arora et al., and S. S Ahmed et al., [7, 8].

The commonest cause of metastasis was found to be Squamous Cell Carcinoma (42\%) in which the primary site was the upper aerodigestive tract. These findings correlated with the study done by K. Mamatha et al., (56\%), Babu G. S et al., (70.6\%). However Ghartimagar D et al., noted most common malignancy was adenocarcinoma seen in 67\% [9-11].
Correlation between cytological and histological examination of lymph node showed diagnostic discordance in only 3 cases

\section{Conclusion}

FNAC is a simple, safe and economic procedure which is less time consuming, with a high degree of concordance with histopathological diagnosis, thereby helps in preventing unnecessary surgery.

\section{REFERENCES}

1. Patel MM, Italiya SL, Patel RD, Dudhat RB. Role of Fine Needle Aspiration Cytology to analyse various causes of lymphadenopathy;Natl J Community Med. 2013;6(4):400-4.

2. Kumar N, Gupta BB, Sharma B, Kaushal M. Role of fine needle aspiration cytology in human immunodeficiency virus associated lymphadenopathy:a cross sectional study from northern India.Hong Kong Med J. 2015;21(1):3944.

3. Hemalatha A, Udhay K. A fine needle cytology of lymph node: a mirror in diagnosis of spectrum of lymph node lesions. $\mathrm{J}$ clin Biomed sci. 2011;1(4);164-72.

4. Shilpa G, Nataraju G. Pattern of lymph node diseases in tertiary level referral centre: A cytological study of 943 cases. International Journal of Biological and Medical Research. 2013:4(3):3448-52

5. Wilkinson AR, Mahore SD. FNAC in the diagnosis of lymph node malignancies: A simple and sensitive tool. Indian Journal of Medical and Pediatric Oncology. 2012; 33(1); 21-4.

6. Shrivastav A, Shah HA, Agarwal NM, Santwani PM, Srivastava G. Evaluation of peripheral 
lymphadenopathy by fine needle aspiration cytology: A three year study at tertiary center. Journal of Dr. NTR University of Health Sciences. 2014 Apr 1;3(2):86-91.

7. Arora B, Arora D. Fine needle aspiration cytology in diagnosis of tuberculous lymphadenitis; Indian Journal on Medical Research; 1990; 91;189-92.

8. Ahmad SS, Akhtar SL. Incidence of tuberculosis from study of fine needle aspiration cytology in lymphadenopathy and acid fast stain; Ind J Com Med. 2005; 30;63-66.

9. Mamatha K, Arakeri SU. Clinicocytological study in evaluating the primary site of tumour in patients presenting with metastatic tumours in lymph node. Asian Journal of Pharmaceutical and Health Sciences. 2014; 4(2); 1001-5.

10. Babu GS, Ramesh G. Cytohistopathological evaluation of the cervical lymph nodes by fine needle aspiration cytology. Journal of crania maxillary diseases. 2014;3(2):101-5.

11. Ghartimagar Ghosh A, Ranabhat S. Utility of fine needle aspiration cytology in metastatic lymph nodes. Journal of Pathology of Nepal. 2011;1:9295 . 